\title{
An American Mystic in the East: Tracing the Origins of Robert Bly's Interest in Persian Literary Tradition
}

\author{
Fazel Asadi Amjad \\ English Language and Literature Department, Kharazmi University, Tehran, Iran \\ Kamran Ahmadgoli \\ English Language and Literature Department, Kharazmi University, Tehran, Iran \\ Qadir Haqiqatshenas \\ English Language and Literature Department, Kharazmi University, Tehran, Iran
}

\begin{abstract}
The American poet Robert Bly is among the most important literary figures in the second half of the $20^{\text {th }}$ century. He worked in various capacities as a poet, translator, teacher and workshop organizer among other things, so much so that he is sometimes compared to Ezra Pound on account of the variety of his interests and the extent of his influence. Like Pound, Bly developed an interest in Asian poetic traditions, including that of Iran, and in doing so, he translated the poetry of Rumi (better known as Mowlana in Iran) and Hafez into English. The present study seeks to trace the paths through which Bly came to develop an interest in Persian mystical poetry and to demonstrate two concerns that guided and informed his interest in this tradition; that is, the socio-political vocation of the poet and the formal advantages of the poetic form known as Ghazal. Such concerns, it will be argued, are firmly rooted within the American literary tradition and therefore this study reveals the continuities that underlie Bly's interest in Persian poetry, suggesting that he sometimes approached Persian poetry on his own terms, without paying proper attention to the context, a shortcoming that, as will be shown, is the result not of ignorance but what may be called methodological laxity.
\end{abstract}

Index Terms-Hafez, mysticism, Robert Bly, Rumi

\section{INTRODUCTION}

The American poet Robert Bly (b. 1926) has been an influential figure on the American literary scene in various capacities since the 1950s. He was the editor of the magazines The Fifties, The Sixties and The Seventies, introduced foreign poets to the American audience through translation of their poetry, and organized poetry workshops and sang poems to an enthusiastic audience, among other things. In fact, he is frequently compared to Ezra Pound (1885-1972) on account of the diversity of his interests and the extent of his influence on other poets. ${ }^{1}$

Bly often enlisted the help of a fellow poet or a scholar to introduce foreign poets to American audience in order to enrich the American poetic tradition which in his opinion "had no bold new poetry since the astounding daring of The Waste Land" (Faas, 1976, p. 709). In doing so, he also showed interest in the Eastern Mystical tradition and particularly the two Persian poets: Rumi (better known as Mowlana in Iran) (1207-1273) and Hafez (1315-1390).

In 1976, Bly showed Coleman Barks (b. 1937) some translations ${ }^{2}$ of the poetry of Rumi, adding that "These poems need to be released from their cages" (Moyers, 1995); he later joined Barks to translate seventeen poems by Rumi in Night \& Sleep (1981); and in 1983, he published When Grapes Turn to Wine "Versions of Rumi by Robert Bly," as the cover page advertised. In translating the poetry of Hafez, Bly was in better company; he published his translation of the poetry of Hafez entitled The Angels Knocking on the Tavern Door; Thirty Poems of Hafez in 2008 with the help of Leonard Lewisohn (1953-2018), "an unfailingly fierce and generous scholar of Iranian literature," as Bly (2004) emphasized in an anthology of poetry in translation (p. vi). The poems are highly annotated by Lewisohn, which is indicative of his knowledge of Persian poetry.

The present paper seeks to investigate Bly's interaction with the Persian poetic tradition. The first section of the paper traces some of the main routes through which Bly came to discover and turn his attention to Eastern poetic tradition and particularly Persian poetry. And the second and third sections address two concerns that informed Bly's interest in the Persian poetry of Rumi and Hafez; that is, Bly's conception of the socio-political role of the poet and the Eastern poetic form known as Ghazal.

\footnotetext{
${ }^{1}$ See, for example, (Kooser, 1994, p. 813; Stitt, 1980, p. 663).

${ }^{2}$ The translations were by Arthur J. Arberry (1905-1969) and Reynold A. Nicholson (1868-1945) (Elmarsafy, 2013, p. 266).
} 


\section{A Meandering Path to Persia}

Robert Bly's literary career took many twists and turns, from the beginning, following his graduation from Harvard in 1950 at the age of 24 . He spent two years at the University of Iowa, attending the Writers Workshop and was granted a Fulbright Scholarship in 1956 to go to Norway in order to translate Norwegian poetry into English. Bly's project was cut short and took a new turn when he came to discover the poetry of Latin American and European poets such as Pablo Neruda (1904-1973) and Georg Trakl (1887-1914) in Oslo in 1956 (Gioia, 1987, p. 210). This event was significant in Bly's later career in more than one way. Bly, first and foremost, realized what was lacking in the American poetry and, returning to the United States, set out to translate European poetry into English, with the aim of enriching the American poetic tradition (Ibid). But the event was also important in opening new possibilities before Bly, which ultimately directed his path towards the Eastern poetic tradition.

One of the important figures in this respect was the Spanish poet Federico Garcia Lorca (1898-1936), whose works greatly influenced American poetry in the 1950s and the 1960s, including that of Robert Bly. ${ }^{3}$ Bly's translation from Lorca appeared in two books of poetry: Lorca and Jiménez Selected Poems, published in 1973 and The Winged Energy of Delight; Selected Translations, published in 2004. In the short prefaces Bly wrote to these books, he referred to the influence of Arabic poetry on Lorca's works. Of course, Lorca himself was more precise when explaining about the influences on Spanish poetry, including his own: "When our songs reach the extremes of pain and love they come very close in expression to the magnificent verses of Arab and Persian [italics mine] poets" (Qualey, 2012, p. 13).

Moreover, the name of Lorca's poetry book and his frequent reference to Eastern poetic forms demonstrate his familiarity with that tradition. His "The Tamarit Divan", contains some poems entitled Qasida and Ghazal, which are Eastern poetic forms; and Bly translated some of them in his edition of Lorca's poetry. Bly ultimately came to write Ghazals of his own too in his poetry book "My Sentence Was a Thousand Years of Joy" published in 2005, in a way which more strictly_compared with Lorca-corresponds with the form of Ghazal, repeating the name of the poet in the last stanza.

Moreover, after Bly's project of translating Norwegian poetry was cut short in 1956, he resumed the project later with two differences: he broadened the scope of the project to include the Scandinavian literature and there was also a new emphasis on the poetry of "inwardness," with free association of images, a shift of emphasis that was mainly the result of discovering European and Latin American surrealist poetry. In doing so, Bly came to know the poetry of the Swedish poet Gunnar Ekelöf (1907-1968), who was influenced by Eastern mystical poetry. In the early 1960s, Bly joined Christina Bratt to publish in The Hudson Review a few poems by Gunnar Ekelöf in translation. In 1975, Ekelöf was again among the three Swedish poets featured in a book of poetry ${ }^{5}$ chosen and translated by Bly; and later, Ekelöf was also present among the many other non-English poets in the anthology of poetry Bly published in 2004, entitled The Winged Energy of Delight: Selected Translations.

From early on in 1962-3, Bly realized and referred to the influence of the "inward thought of the Orient" on Ekelöf's poetry (Bratt and Bly, 1962-1963, p. 546), a characteristic (i.e. inwardness) that came to be a staple of his conception of what genuine poetry is; and he later identified Persian mystical poetry and French poetry as the two sources, outside the Scandinavian tradition, for Ekelöf's poetry early on in his career ${ }^{6}$ (Bly, 2004, p. 208; Smith, 2013). The realization that Eastern (particularly Persian) poetry influenced poets such as Lorca and Ekelöf, as demonstrated above, encouraged Bly to turn his attention to the Eastern poetic tradition, as a result of which he developed an interest in the Eastern and particularly Persian poetry in terms of style (poetic forms) as well as on account of the quality of inwardness and spirituality present in this mystical tradition; and he set out to translate the Persian poetry of Rumi and Hafez into English.

Of course, other factors also played a part in encouraging Bly and strengthening his interest in the Eastern poetic tradition. For example, in an interview, published in 2000, Bly remarked that his son-in-law "who was born in Jaipur [i.e., a city in India], asked me to help him a few years ago to translate some poems of the Indian poet Ghalib [17971869], who lived in the 19th century and wrote in Urdu, which is a mixture of Persian [Italics mine] and Hindi" (Quinn, 2000). ${ }^{7}$ In turning to Persian poetry, Bly's interest was informed by two important considerations, which will be discussed in some detail below; that is, his conception of the socio-political vocation of the poet, and the formal advantages of the Ghazal as a poetic form.

\section{Bly AND Socio-Political Role of the PoEt}

Robert Bly is among the American poets whose life and poetry are greatly shaped by the contemporary political

\footnotetext{
${ }^{3}$ See (Chamberlain, 1985, p. 434) and (Sadoff, 1980, p. 18). And Bly discusses Lorca's role in American poetry in his 1990 book American Poetry: Wildness and Domesticity.

${ }^{4}$ The term "Divan" itself comes from the Persian diwan, meaning "collection" of poetry (Lorca, 2007, p. 182).

${ }^{5}$ The book was entitled Friends, You Drank Some Darkness. Three Swedish Poets: Harry Martinson, Gunnar Ekelöf, and Tomas Tranströmer.

${ }^{6}$ Ekelof's interest in the East was indeed strong. He attended the School of Oriental Studies in London and "read Persian and Sanskirit in Uppsala" (Bly 2004, p. 208); he wrote on Islamic themes (Daruwalla, 2001, p. 172); and he was fascinated by the Oriental mysticism (Sjöberg, 1970, p. 101).

${ }^{7}$ There are other factors, which were significant in drawing Bly's attention to the Eastern poetic tradition, such as Buddhism and Haiku poetry, among other things. Bly mentions some of them in an interview (Shakarchi and Bly, 1982, p. 229). But here factors particularly related to Persian poetic tradition are relevant.
} 
developments. He believed in the socio-political role of the poet and did not, to quote Biespiel (2010) on a different matter, merely "moonlight" as a cultural writer (p. 151), because he genuinely had faith in the transformative power of poetry and worked actively to bring about change in the society. In 1967, in an essay entitled "On Political Poetry," Bly elaborated on his idea of what political poetry consisted in, emphasizing his opinion about the necessity of "inwardness" in poetry: "what is needed to write true poems about the outward world is inwardness; [and poets need to] penetrate the husk around their own personalities" and delve into their psych, so that they may "speak of inward and political things with the same assurance" (Hickman, 2015, p. 94).

The necessity of access to the psyche in the case of poetry and politics suggests that Libby (1972) is right, in his assessment of Bly's poetry, when he locates the origin of both poetry and politics in the mind (p. 82). Elaborating on this point, Bly likened the life of a nation to the psyche of an individual, but on a larger scale. Only a poet with a good "grasp of his own concerns [...] can leave them for awhile," delve into the socio-political consciousness and emerge successfully with what can genuinely be called political poetry ${ }^{8}$ (Faas, 1976, p. 714).

Of course, Bly's tendency to infuse his poems with political themes or, as one of his critics put it, to "marry the Muse ... to politics," (Gwiazda, 2005, p. 169) invited much criticism. And many of the attacks, as Bly explained, came particularly from the academia by the university professors (Quinn, 2000). Bly was aware of the possible problems attending political poetry, and tried to clarify what he thought about political poetry on several occasions in interviews. For example, in an interview in 1976, praising Lorca's poems because of their genuine "images", Bly asserted that "Most political poetry [in the United States] is barn-door poetry" in comparison (Faas and Bly, 1976, p. 683). And in another interview in 1982, when the interviewer said that some critics believed Bly's poetry-and that of Gary Snyder (b. 1930)—were too "moralistic," "didactic" and "instructive," he replied:

Who knows? They may be right. You can never say anybody's wrong. But if I were asked about it, I would say that I understand the poem to be a container of energy, and the more kinds of energy in the poem the better. [...] In the Confucian world, you give instruction in a poem; the poem lays out certain rules to help people live decently. Snyder does a lot of that. Some people connect such instruction with high school principals and stuff, but I don't. I consider it to be a good form of energy, a true form of energy, if the instruction is intelligent. (Shakarchi and Bly, 1982, p. 233)

The last clause is of great importance. While political poetry may be didactic, it does not, in Bly's opinion, necessarily seek to encourage us to take a particular course of action but instead tries to deepen our awareness (Ghazoul, 1986, p. 107). Therefore, among Bly's favorite poets, we can find figures who were actively political (like Neruda and W. B. Yeats) as well as those who were so in a broad sense of the word (like the Indian poet Mirabai (1498-1547)).

There are three main factors that are of significance in shaping Bly's interest in politics and his conception of the poet with a socio-political calling. This section addresses these three factors, i.e., the Vietnam War, the American literary tradition, and the influence of foreign poets (whose works Bly translated into English), with the aim of demonstrating how similar socio-political concerns guide and direct his interest in the Persian poetry, particularly that of Hafez.

The Vietnam War (1954-75) was a significant event in American history in the 1950s. Bly, who preferred the secluded quietude of the countryside before the start of war, became very vocal from the start in his opposition to the Vietnam War and he expressed it both in his poetry and his life. His poems about the war were published in the poetry book "The Light Around the Body" (1967) and he submitted the National Book Award check he received in 1968 for the same book to a draft-resistance organization (Beisner, 1970, p. 210).

As Bly emphasized in an interview (Quinn, 2000), he had already been working on political poems before the beginning of the Vietnam War, but the war was indeed a turning point in Bly's poetry, giving a more political bent to his "romantic emphasis on "inwardness"" (Suarez, 1991, p. 81). It is mainly as a result of this experience that, for Bly, the poetry of inwardness and political activism are combined. Of course, Bly's tendency in combining the mystical and the political impulses should be analyzed in the tradition of American poets like Ralph Waldo Emerson (1803-1882) and Henry David Thoreau (1817-1862) — who were incidentally a great influence on Bly ${ }^{9}$ — and within the context of the debates about the role of the poet in the society.

Oliver Wendell Holmes (1809-1894), for example, criticized Emerson's pragmatic mysticism, believing it would disrupt the status quo in the society. Holmes was particularly more concerned about Emerson's more radical followers who, as a result of Emerson's teachings, would seek to bring about change in the society such as pursuing women's rights, pushing for radical political reforms, etc. (Weinstein, 2006, pp. 143-144).

The same combination of the mystical and political impulses can be seen in Thoreau's works, who was a pantheist, with little regard for institutionalized religion, and a rebellious soul who espoused a kind of qualified Unitarianism in line with his transcendentalist principles (Greeley, 1974, p. 18). As Libby (1972) says, Like Thoreau, Bly gradually developed an interest in "the politics of American imperialism" (p. 81), chiefly as a result of the Vietnam War. In 1967, Bly refused to receive the $\$ 5,000$ grant offered by the Foundation on the Arts and the Humanities to the Sixties Press

\footnotetext{
${ }^{8}$ For Bly, poets who wrote great political poems include: Pablo Neruda, W. B. Yeats (1865-1939), W. V. Moody (1869-1910) and Walt Whitman (1819-1892), to name a few (Faas, 1976, p. 714; Brown, 1973, p. 60).

${ }^{9}$ See, for instance, (Shakarchi and Bly, 1982, p. 231), where Bly acknowledges his debt to Thoreau and Emerson; and (Suarez, 1991, p. 81), where Richard Sugg suggests that Bly's poetry is in the romantic tradition of these two American poets.
} 
'Since the [US] Administration is maiming an entire nation [i.e. the Vietnamese] merely to advance our national interest" (Hickman, 2015, p. 93); and in 1968, in his acceptance speech at the National Book Award ceremony, Bly used the opportunity to criticize the US's foreign policy, stating that we are "murdering a culture in Vietnam at least as fine as our own" (Molesworth, 1975, p. 97). ${ }^{10}$

This socio-political conception of the role of poet can also be observed in Bly's activities in the capacity of the translator of foreign poetry into English. Perhaps, Pablo Neruda who is called "Noble laureate, international diplomat and political activist in one" (Bleiker, 1999, p. 1129) is the best example to illustrate this point. Bly discovered Neruda in a library in Oslo short after 1956 when he received the Fulbright Fellowship to translate and introduce Norwegian poetry to the American readers, and he immediately realized Neruda's poetry was quite different from what he had read in the American tradition. Taking the New Critics to task for being completely "blind" to foreign poetry, Bly seems to be at first impressed with the surrealism in Neruda's poetry (Quinn, 2000); but the socio-political aspect of the life of the poet gradually became of great significance to him, a fact evident in many of the short introductions that accompany Bly's translations, and he drew attention to the foreign poets' roles in engaging critically with the status quo.

In the preface to the book Neruda and Vallejo; Selected Poems, Bly remarked that Neruda, who struggled all his life to "keep Chile from returning to right-wing control," wrote poems that included "careful nature observation, geology, accounts of European invasion, North American meddling, and rage" (Bly, 1993), making a case for the relevance and significance of Neruda's poetry for the American audience; and he praised the Peruvian poet César Vallejo's (18921938) political writing, asserting that it "belongs with" the political writings of Bertolt Brecht (1898-1956) and Nazim Hikmet (1902-1963) (Ibid). The same is true about Bly's prefaces to the translation of the poetry of the Spanish poet Antonio Machado (1875-1939) ${ }^{11}$ and of the Hindu poet Mirabai ${ }^{12}$ (c. 1498-c. 1546) as well as the Spanish poet Juan R. Jimenez (1881-1958) and the French poet Francis Ponge (1899-1988), among others, who are featured in Bly's anthology The Winged Energy of Delight; Selected Translations.

And again the same attention to socio-political concerns can be identified in the prefaces written to Bly's translations of the poetry of the Persian poets, particularly Hafez. Leonard Lewisohn (who joined Bly in the translation of Hafez's poetry, published in 2008) referred to Hafez's "most bitter attacks on orthodoxy" during the "orthodox [and] harsh" reign of Muzaffarid Mobarez-al-Din Muhammad (1318-1363) (Bly and Lewisohn, 2008, p. 72). And Bly, in his short preface to the same book, highlights "aggressive attack[s] on fundamentalists" among other themes in Hafez's poetry (Ibid, p. v).

Bly seems to be more reserved in depicting Rumi as a political poet, but in his preface to the translation of this Persian poet's poetry (Bly 2004, p. 332), he did refer to the uneasy status of Sufis in orthodox Islam and the problems they suffered through in Muslim communities, citing as an example, the famous mystic Hallāj (c. 858-c. 922), who was imprisoned and then hanged to death on account of his controversial views as well as attempting political reform ${ }^{13}$ at a time when Baghdad was rife with political conflict (Mojaddedi, 2003). And Rumi, interestingly, frequently referred to Hallāj in his works and identified with him. ${ }^{14}$ In other words, although Rumi did not engage in politics, for instance the way Neruda did, his ideas were very controversial when compared with the mainstream Islam, ${ }^{15}$ and it is exactly the fact that Rumi represented something more than the mainstream Islam, which attracted the attention of Coleman Barks and his mentor Robert Bly. Barks (2014) wrote in the introduction to the book Rumi; Soul Fury: "I'm not interested in placing these poems in a particular religious tradition. Rumi was a devout Muslim, a Sufi. [...] But he has also been heard as a more universal voice."

As the outline above shows, out of the 1950s and the 1960s, Bly gradually emerged as a poet with a political calling, and his conception of the role of poet was shaped and influenced by American poets (such as Emerson and Thoreau), the contemporary political developments (the Vietnam War), and Bly's encounter with foreign poetry (such as that of Neruda). And such socio-political concerns can be traced in his prefaces to the foreign poetry he translated into English, including that of Persian poets, showing that the socio-political role of the poet was a guiding principle in his interest in foreign poetry throughout his career.

\section{BLy AND THE POETIC FORM: GHAZAL}

Bly's socio-political tendencies were not confined to poetic subject matter and he sought to revive and promote the prose poem — which in his opinion could be traced back to an ancient form, the fable (Horvath, 1992, p. 11) - as "the rhymed metered poem is, in our consciousness, so tied to the feudal stratified society of England that such a metered poem refuses to merge well with the content of American experience" (Bjorklund, 1995, p. 549). In trying to free poetry from its conventional metric limitations, Bly belongs to the tradition of American poets like Walt Whitman and Emily

\footnotetext{
${ }^{10}$ In 2003, Bly was also among the many poets who signed a document entitled “A Plea for Reflection” to voice their dissent (Morrissey, 2003, p. 16).

${ }^{11}$ The book is entitled Times Alone; Selected Poems of Antonio Machado, published by Wesleyan UP in 1983.

12 The book is entitled Mirabai; Ecstatic Poems, published by Beacon Press in 2004.

${ }^{13}$ Hallāj's involvement in the political reform is not an established fact. As J.W. Fiegenbaum observes, "The alleged involvement of al-Hallāj in an attempt at political and moral reform upon his return to Baghdad was an immediate factor in his arrest" (paragraph 7).

${ }^{14}$ See (Najjari and Ahmadnejad, 2013), which is a study of the role of Hallaj in Rumi's works.

${ }^{15}$ See, for instance, (Masroori, 2010), where he investigates Rumi's "criticism of religious persecution."
} 
Dickinson (1830-1886) who avoided using iambic pentameter to a great extent (Finch, 2005, p. 148). While Whitman chose dactylic rhythms and Dickinson favored hymn stanza, Bly adopted the prose poem believing it "is the final stage of the unpretentious style" more suitable for the expression of "complicated human perceptions" (Sajé, 2014, p. 148) and that it is "the suppler form for the embodiment of the mind's action" (Dana, 1990, p. 79). ${ }^{16}$

The last quote, with its emphasis on the interrelation of mind and poetic form, demonstrates Bly's association with a movement that came to be called "deep image" poetry. ${ }^{17}$ The term signifies the "expression of psychic force which suddenly becomes language" (Faas, 1976, p. 710). In other words, the prose poem yields itself more easily to "psychic leaps" between "the quotidian and the unconscious" (McFarland, 1997, p. 257), bringing images into close association, which results in powerful metaphors with "equal footing in the familiar and the strange" (Bond, 2015, p. 161).

In a statement that brings to mind Eliot's remarks about the dissociation of sensibility in its sweeping generalization, Bly asserts that European poetry gradually failed to produce powerful associations sometime in the thirteenth century, with Geoffrey Chaucer (c. 1342/43-1400) and William Langland (c. 1330-c. 1400) already showing signs of this decline, and by the eighteenth century, the situation was at its worst when poetry became almost intellectual and imagination was forgotten. It was William Blake (1757-1827) who first "abducted the thought of poetry and took it off to some obscure psychic woods" (Bly, 1975, pp. 5-6).

For Bly, this leaping quality could also be observed in the poetry of poets like Machado, Jimenez, Neruda and Lorca, whom he translated into English. As an example, Bly mentions, in an essay titled "Looking for Dragon Smoke," Neruda's "Nothing But Death," where the poet "leaps from death to the whiteness of flour, then to notary publics" and so on (Ibid, p. 4). This free association of various images, for Bly, is best evident in surrealism, as in a revealing statement he uses the words "leaping" and surrealist" interchangeably, when comparing Spanish and French surrealist poetry ${ }^{18}$ (Ibid, p. 40). The liberating force of surrealism allowed the mind to go back and forth between the conscious and the unconscious with equal facility. And Bly embarked on the dual mission of promoting "leaping" poetry and translating Spanish poetry into English because he believed that the reason for the lack of vigor in American poetry was due to the fact that "other poetries have passed through surrealism; we have not" (Faas, 1976, p. 709).

Bly believed the fact that American poetry suffered in this regard was evident in the poetry of Ezra Pound and Imagist poets, where the poem is composed of "pictures" rather than images. He wrote in The Fifties that Imagism was a misnomer because Imagist poets "did not write in images from the unconscious" (Ibid, p. 710) ${ }^{19}$; he hoped in 1962 that the American "poetry of pictures" would be replaced by a poetry originating from "the inward world" (Yenser, 1982, p. 32), like those of Vallejo, Neruda and Lorca, among others.

Such considerations about poetry and its form led Bly to the translation of poetry from other traditions, first from Spain and Latin America and then from the East and particularly Iran. And interestingly, the same concerns (i.e. the leaping quality of poetry as well as its being rooted in the inward world) inform his interest in Persian poets, chief among them, Rumi and Hafez. Although Bly never learned Farsi (i.e. the Persian language), immediate experience of Iranian culture ${ }^{20}$ and seeking help from scholars ${ }^{21}$ helped him gain some knowledge of Persian poetry and mysticism, a fact evident not only in the collections of poems he translated from Farsi, but also in his occasional comments about the poetic forms used in Persian poetry.

Bly frequently drew attention to the free association of images in the Eastern poetic form known as Ghazal. For instance, he described the form of the Ghazal, as written by the Indian poet Ghalib (1797-1869), in this way: "No clear thread unites all the couplets. It slowly becomes clear that we are dealing with a way of adventuring one's way through a poem utterly distinct from our habit of textual consistency in theme" (Bly 2004, p. 362). And he expressed similar thoughts about the Ghazals of the Persian poet Hafez on several occasions.

In an interview in 2000, for example, Bly described the form in the context of Persian poetry thus: "the Ghazal often makes a leap to a new subject matter with each new stanza [which is] a form of wildness" (Quinn, 2000). He struck a similar note when he compared the poetry of Hafez to the movement of the hands in a Bach prelude: "The left hand goes on talking of failure and repentance, and the light, quick right hand talks about the magnificence of poetry and religion, of the side glances given to us by God" (Bly 2004, pp. 377-378) while the whole poem is tied together by an invisible center. And again, trying to emphasize the difference of Hafez's poems from those in the Anglo-American tradition by William Wordsworth (1770-1850) and Wallace Stevens (1879-1955), Bly remarked that the poetry of Hafez "moves in a jagged manner" and the poem begins "again with each stanza" (Bly and Lewisohn, 2008, p. v). As Kashani (2014) states, "Bly appreciated the skillful use of metaphors in Hafez's ghazals through which he brings several points of views together within one ghazal” (p. 113).

\footnotetext{
${ }^{16}$ Bly also promoted the prose poem as "the natural speech of a democratic language" (Lehman, 2003, p. 49) and considered it particularly suitable as "no one has set up the standards yet" for it (Hetherington and Atherton, 2020, p. 13).

${ }^{17}$ The term was coined by Robert Kelly and Jerome Rothenberg in 1961 (Faas, 1976, p. 710), and Bly did not like the coinage (Hetherington and Atherton, 2020, p. 109).

${ }^{18}$ Bly, it is worth noting, preferred Spanish surrealism to French surrealism, a fact he expressed on different occasions. See, for instance (Bly, 1993), where he stated that "French surrealist poems appear drab and squeaky" and (Quinn, 2000), where he remarked that "Most of the images of French surrealism don't have a center."

${ }^{19}$ Barone (1982) also expounds on the significance of the role the mind plays in Bly's conception of the image (p. 120).

${ }^{20}$ He came to Iran, accompanied by Coleman Barks, in 2006.

${ }^{21}$ For example, in translating the poetry of Hafez, he enjoyed help from the scholar of Iranian literature, Leonard Lewisohn (Bly, 2004, p. v)
} 
The same free association of poetic images and elements can be seen in the poetry of Rumi. The famous Iranian Rumi scholar Abdolkarim Soroush (2006) described the experience of composing poetry by Rumi thus:

the warm, raw experience of the words [come] to his [i.e., Rumi's] lips through his mind-he is like a man swimming when he plunges into the depths of the sea. You never know from where he might next emerge. So you cannot follow him, because the steps are not, strictly speaking, logical. He moves with free associations; that is the formula. (p. 282)

Coleman Barks, who worked closely with Bly on translating the poetry of Rumi into English, identified similar features in the words of Rumi's mentor, Shams, collected in a book entitled The Sayings of Shams. Barks (2014) stated that "Shams' sentences do not proceed logically," tracing what he thought to be a kind of "numinous structure" in them. It is therefore no wonder that Bly (2004) considered Rumi to be "more an excitable library of poetry than a person" and when he encountered Rumi's poetry, he "at once [...] felt at home" (p. 331).

As demonstrated, Bly clearly found interesting the free association of different ideas and images in the Persian mystical poetry. And particularly the poetic form known as Ghazal, infused with the mystical poetry of Hafez and Rumi (with its emphasis on the spiritual and "the inward world"), was adopted by Bly and he used it in many of his poems. Bly in an interview referred to the influence of Rumi on his poetry book "This Body Is Made of Camphor and Gopherwood" (1977) (Quinn, 2000), and a reviewer of his poems remarked that Bly "brilliantly adopts this richlysymbolic, philosophically-inclined form," i.e. Ghazal in the poetry book "The Night Abraham Called to the Stars" (2001) (Taylor, 2002, p. 45), citing Rumi and Hafez as examples.

Bly's interest in the Eastern poetic form Ghazal can be traced back to his dissatisfaction with the state of affairs in American poetry of the 1950 s and the 1960s as well as his original ideas about how American poetry should be transformed. And as Bly was a poet with an international frame of mind, he investigated Eastern poetry to find new poetic forms, which corresponded to his ideas about the free association of images in poetry.

\section{CONCLUSION}

Throughout his career, Robert Bly worked in various capacities as poet, editor, translator, etc. to broaden the scope of American poetry and set right what he believe to be wrong about it. In doing so, he adopted themes and poetic forms from cultures so different and distant from his own, including that of Persia. This paper sought to show how Bly became familiar with the Persian poetic tradition, and to demonstrate how his interest in Persian poetry was informed by his concerns about the poetic form as well as his conception of the socio-political role of the poet. It further tried to show how such concerns originate in the American literary tradition.

Furthermore, the present paper reveals implications that could be the subject of another study. By revealing the continuities that underlie Bly's interaction with Persian mystical poetry, this study demonstrates that Bly usually approached Persian poetry on his own terms. Therefore, it is no wonder that sometimes he misrepresented Persian poets and poetry, focusing on the aspects that interested him. ${ }^{22}$ And this is a point more evident in the case of Rumi, as Bly was not accompanied by a scholar well-versed in Persian poetry, in translating the poetry of Rumi.

Of course, Bly himself was aware of the problems attending translation of literary works and how themes and ideas could be distorted in the process of translation. In an interview, he remarked that "We are all tourists of the East, all Westerners are, and we take their concepts and we misuse them constantly... It's exploitation not different from what the American soldier did in Vietnam" (Faas and Bly, 1976, p. 691). And he believed that a translation, at its best, "resembles a Persian rug seen from the back - the pattern is apparent, but not much more" (Liro, 1992, pp. 71-72). Therefore, he sometimes called his translations "versions" to indicate that they were reworkings of the original (Bly, 2004, p. vi), emphasizing, in the introduction to his translation of the poetry of Hafez, that loss of meaning is an unfortunate but inevitable result of the process of translation (Bly and Lewisohn, 2008, p. vii).

Given that Robert Bly has been an important figure in facilitating the transmission of Persian poetry in the American culture, it is necessary to investigate the manifestation of Persian poetry in Bly's poetry as well as translations, and to identify the ways in which it has been qualified or contorted in the process of translation. ${ }^{23}$ Having said that, although Bly was occasionally inaccurate and always controversial, he has been an indispensable figure on the American literary scene since the 1950s; and the original poetry he composed and the foreign poetry he translated remain a very readable and worthy legacy, which attest to his merits both in the capacity of a poet and a translator.

\section{REFERENCES}

[1] Barks, Coleman. (2014). Rumi: soul fury; Rumi and Shams Tabriz on friendship. HarperOne, EPUB.

[2] Barone, Dennis. (1982). Under the silence of the unfinished work. boundary 2, 10.2, 115-134.

[3] Beisner, Robert L. (1970). 1898 and 1968: The anti-imperialists and the doves. Political Science Quarterly, 85.2, 187-216.

\footnotetext{
${ }^{22}$ See, for instance, (Elmarsafy, 2013, pp. 269-270), where he finds fault with Bly's reference to the relationship between Rumi and Shams in the context of male bonding in his (i.e. Bly's) work Iron John.

${ }^{23}$ Anoosheh and Jahromi (2020) have recently written about the translation of Hafez's poetry by Bly and Lewisohn in the paper "A Mystical Reading of Hafiz's Translation by Robert Bly and Leonard Lewisohn." It would be best to build on their paper and broaden its scope in order to cover Bly's opinions about Hafiz expressed, for instance, in his anthology of poetry in translation The Winged Energy of Delight and the quotes from Hafez he used in his other books, such as the book More Than True: The Wisdom of Fairy Tales.
} 
[4] Biespiel, David. (2010). This land is our land. Poetry, 196.2, 151-158.

[5] Bjorklund, Beth. (1995). Form, anti-form, and informality: Reinventing free verse. Poetics Today, 16.3, 547-567.

[6] Bleiker, Roland. (1999). Pablo Neruda and the struggle for political memory. Third World Quarterly, 20.6, 1129-1142.

[7] Bly, Robert and Leonard Lewisohn. (2008). The angels knocking on the tavern door: Thirty poems of Hafez. HarperCollins.

[8] Bly, Robert. (1975). Leaping poetry: An idea with poems and translations. University of Pittsburgh Press.

[9] Bly, Robert. (1993). Neruda and Vallejo: Selected poems. Beacon Press. EPUB.

[10] Bly, Robert. (2004). The winged energy of delight: Selected translations. HarperCollins.

[11] Bond, Bruce. (2015). Immanent distance: Poetry and the metaphysics of the near at hand. University of Michigan Press.

[12] Bratt, Christina and Robert Bly. (1962-1963). Translations from Gunnar Ekelöf. The Hudson Review, 15.4, 546-550.

[13] Brown, Maurice F. (1973). William Vaughn Moody (1869-1910). American Literary Realism, 1870-1910, 6.1, 51-60.

[14] Chamberlain, Lori. (1985). Ghostwriting the text: Translation and the poetics of Jack Spicer. Contemporary Literature, 26.4, 426-442.

[15] Dana, Robert. (1990). In the labyrinth: Poetry as prose; Prose as poetry. The North American Review, 275.3, 72-80.

[16] Daruwalla, Keki N. (2001). Identity: Language, literature, writer. Indian Literature, 45.2, 168-176.

[17] Elmarsafy, Ziad. (2013). User-friendly Islams: Translating Rumi in France and the United States. In Evelyn A. Alsultany and Ella H. Shohat (eds.) Between the middle east and the Americas: The cultural politics of diaspora. The University of Michigan Press, 264-281.

[18] Faas, Ekbert and Robert Bly. (1976). An interview with Robert Bly. boundary 2, 4.3, 677-700.

[19] Faas, Ekbert. (1976). Robert Bly. boundary 2, 4.3, 707-726.

[20] Fiegenbaum, J.W. Al-Ḥallāj. In Encyclopedia Britannica. Retrieved June 03, 2021. available online at: https://www.britannica.com/biography/al-Hallaj.

[21] Finch, Annie. (2005). The body of poetry: Essays on women, form, and the poetic self. University of Michigan Press.

[22] Ghazoul, Ferial J. (1986). The poetics of the political poem. Arab Studies Quarterly, 8.2, 104-119.

[23] Gioia, Dana. (1987). The successful career of Robert Bly. The Hudson Review, 40.2, 207-223.

[24] Greeley, Dana McLean. (1974). Review of Thoreau: Mystic, prophet, ecologist, by William Wolff. The Concord Saunterer, 9.2, 18.

[25] Gwiazda, Piotr. (2005). 'Nothing else left to read': Poetry and audience in Adrienne Rich's an atlas of the difficult world. Journal of Modern Literature, 28.2, 165-188.

[26] Hetherington, Paul and Cassandra Atherton. (2020). Prose poetry: An introduction. Princeton University Press.

[27] Hickman, Ben. (2015). Crisis and the US avant-garde; Poetry and real politics. Edinburgh University Press.

[28] Horvath, Brooke. (1992). The prose poem and the secret life of poetry. The American poetry review, 21.5, 11-14.

[29] Kashani, Neda Ali Zadeh. (2014). Adrienne Rich's ghazals and the Persian poetic tradition: A study of ambiguity and the quest for a common language. Università Degli Studi Di Macerata.

[30] Kooser, Ted. (1994). Review: Five chapbooks out of many. The Georgia Review, 48.4, 812-821.

[31] Lehman, David. (2003). The prose poem: An alternative to verse. The American Poetry Review, 32.2, 45-49.

[32] Libby, Anthony. (1972). Robert Bly alive in darkness. The Iowa Review, 3.3, 78-89.

[33] Liro, Joseph. (1992). Stanislaw Lem in translation: A linguistic commentary. The Polish Review, 37.1, 45-72.

[34] Lorca, F. G. (2007). Selected poems. Translated by Martin Sorrel. Oxford University Press.

[35] Masroori, Cyrus. (2010). An Islamic language of toleration: Rumi's criticism of religious persecution. Political Research Quarterly, 63.2, 243-256.

[36] McFarland, Ron. (1997). 'Another kind of violence': Sherman Alexie's poems. American Indian Quarterly, 21.2, $251-264$.

[37] Mojaddedi, Jawid. Hallāj, Abu'l-MoḠiT Hosayn. In Encyclopaedia Iranica, 2003, XI/6, pp. 589-592. Retrieved June 02, 2021. available online at http://www.iranicaonline.org/articles/hallaj-1

[38] Molesworth, Charles. (1975). Thrashing in the depths: The poetry of Robert Bly. Rocky Mountain Review of Language and Literature, 29.3/4, 95-117.

[39] Morrissey, Sinead. (2003). War on Iraq: Against all rhyme and reason. Fortnight, 413, 16-17.

[40] Moyers, Bill. (1995). The language of life: A festival of poets. Doubleday.

[41] Najjari, Mohammad and Kamel Ahmadnejad. (2013). Hallaj in the works of Rumi (AKA Mowlana). Mystical and Mythological Quarterly. 3.32, 219-231. [In Persian].

[42] Qualey, M. Lynx. (2012). Form and sensuality. American Book Review, 34.1, 13-14.

[43] Quinn, Francis. (2000). Robert Bly: The art of poetry. The Paris Review. Retrieved June 5, 2021. Available online at: https://www.theparisreview.org/interviews/729/the-art-of-poetry-no-79-robert-bly

[44] Sadoff, Ira. (1980). The power of reflection: The reemergence of the meditative poem. The American Poetry Review, 9.6, $18-21$.

[45] Sajé, Natasha. (2014). Windows and doors: A poet reads literary theory. University of Michigan Press.

[46] Shakarchi, Joseph and Robert Bly. (1982). An interview with Robert Bly. The Massachusetts Review, 23.2, 226-243.

[47] Sjöberg, Leif. (1970). The latter poems of Gunner Ekelöf: Diwan and Fatumeh. Mosaic: An Interdisciplinary Critical Journal, $4.2,101-115$.

[48] Smith, Thomas R. (2013). AIRMAIL: The letters of Robert Bly and Tomas Tranströmer. Graywolf Press. EPUB.

[49] Soroush, Abdolkarim. (2006). Jalaluddin Rumi: The son of the sun. in Jahrbuch 2004/2005. Wissenschaftskolleg zu Berlin.

[50] Stitt, Peter. (1980). Review: The world at hand. The Georgia Review, 34.3, 661-670.

[51] Suarez, Ernest. (1991). Emerson in Vietnam: Dickey: Bly and the New Left. The Southern Literary Journal, 23.2, 77-97.

[52] Taylor, John. (2002). Review of The night Abraham called to the stars, by Robert Bly. Poetry, 180.1, 45-47.

[53] Weinstein, Michael A. (2006). The imaginative prose of Oliver Wendell Holmes. University of Missouri Press.

[54] Yenser, Stephen. (1982). Sea changes: On Dave Smith. The American Poetry Review, 11.1, 32-35. 
Fazel Asadi Amjad is a Professor in English Literature at Kharazmi University, Tehran, Iran.

Kamran Ahmadgoli was an Associate Professor in English Literature at Kharazmi University, Tehran, Iran. We lost him in the COVID-19 pandemic in July 2021. May his soul rest in peace!

Qadir Haqiqatshenas is a Ph.D. candidate in English Literature at Kharazmi University, Tehran, Iran. 